\title{
Total Reflection X-Ray Fluorescence: A Valuable Analytic Tool for Environmental and Biological Studies
}

\author{
Vanesa N Salomone ${ }^{1,2 *}$, Marina Riera ${ }^{1,3}$ and Claudia Muniain ${ }^{1,2}$ \\ ${ }^{1}$ Consejo Nacional de Promoción Científica y Técnica (CONICET), Buenos Aires, Argentina \\ ${ }^{2}$ Instituto de Investigación e Ingeniería Ambiental, Universidad Nacional de San Martín, Buenos Aires, \\ Argentina
}

${ }^{3}$ Departmento de Biología y Ambiente, Facultad de Ciencias Naturales, Universidad Nacional de la Patagonia San Juan Bosco (UNPSJB), Comodoro Rivadavia, Chubut, Argentina

\begin{abstract}
This review collects the research of the recent years on biological or environmental studies in which Total Reflection X-Ray Fluorescence Spectrometry (TXRF) was used as a chemical analytical technique for quantification of elemental content. Although it is not a novel technique, its application in biological and environmental samples has extended in the last years.

TXRF is a useful analytical technique used for simultaneous qualitative and quantitative determination of a wide range of chemical elements, from sodium until uranium, including halogens with low matrix interferences. The major advantages of this technique include the small amount of sample required and the relative simplicity of sample preparation. Direct analysis of samples is also possible, shortening preparation time, reducing reactive consumption, and simplifying the whole analysis process. Furthermore, the low detection limit makes TXRF an excellent technique for the determination of ultra-trace, trace and major elements (concentrations range from ppb to percent) in environmental and biological samples.
\end{abstract}

Keywords

TXRF applications, Multi-elemental technique, Heavy metals

\section{Abbreviations}

ICP-MS: Inductively Coupled Plasma-Mass Spectrometry; ICP-OES: Inductively Coupled PlasmaOptic Emission Spectroscopy; AAS: Atomic Absorption Spectroscopy.

\section{Introduction}

Elemental content of environmental and biological samples is useful and of great importance for many purposes. TXRF technique makes it possible in a quick, simple manner and at a low cost. For instance, elemental composition of food is of great importance. Food is the main source of essential, major and trace elements for animals and humans. Some potentially toxic elements, dangerous for human health, may contaminate food by entering in the food chain from the environment or during processing or storage. For this reason, the elemental analysis of food is fundamental for safety assessment. Fast and sensitive analytical techniques, able to detect major and trace elements, are required as a result of the increasing demand on multi-elemental information and product screening [1]. The same occurs with the determination of toxic ions in drinking water samples. The World Health Organization (WHO) recommends

*Corresponding author: Dra. Vanesa N Salomone, Investigador CONICET, Instituto de Investigación e Ingeniería Ambiental (3iA), Universidad Nacional de San Martín (UNSAM), Campus Miguelete, 25 de Mayo y Francia, (1650) San Martín, Prov. Buenos Aires, Argentina, Tel: 54-11-40061500/47241500, Int: 6021, E-mail: vsalomone@unsam.edu.ar

Received: May 30, 2017: Accepted: August 04, 2017: Published: August 07, 2017

Copyright: (c) 2017 Salomone VN, et al. This is an open-access article distributed under the terms of the Creative Commons Attribution License, which permits unrestricted use, distribution and reproduction in any medium, provided the original author and source are credited. 
very low levels of most heavy metals in water for human consumption [2]. This group includes $\mathrm{Ag}, \mathrm{Cd}, \mathrm{Cr}, \mathrm{Hg}$, $\mathrm{Pb}, \mathrm{V}$ and some metalloids such as $\mathrm{As}, \mathrm{Sb}, \mathrm{Bi}$, and $\mathrm{Se}$. Therefore, to have a tool that allows quantified simultaneously to all of them, with low limit of detection and high sensitivity, results advantageous.

Heavy metals accumulation in soil, sediments, and ground water may be related to the phenomenon of bioaccumulation ability of living organisms, such as plants and animals. Bioaccumulation is the increase in concentration at human organism due to industrial activities and the food chain. The main sources of heavy-metal pollution in soil are irrigation, especially with sewage; solid-waste disposal, for example, sludge and compost refuse; the use of pesticides and fertilizers; and atmospheric deposition. Plants and algae acquire the essential nutrients, such as $\mathrm{N}, \mathrm{P}$, and $\mathrm{K}$, from the environment. However, they may also accumulate unnecessary and toxic metals, such as $\mathrm{Pb}$ and $\mathrm{Cd}$ [3]. Several plants and macro algae, especially the brown ones, have the ability to accumulate high metal concentrations [4]. Many studies have reported data for the transfer of heavy metals from oil to plants and vegetables through roots and shoots. Finally, these toxic elements can cause possible damage to animals and people that consume them [5].

The elemental evaluation of different biological samples, including human samples, has become more common. Elemental analysis of the human biological material (e.g. saliva, serum, urine, and hair) carries essential information about the state of the organism [6]. One example is the study of environmental and occupational exposure to lead as potential risk factor of cardiovascular diseases [7].

\section{Multi-elemental analysis by Total Reflection X-ray Fluorescence}

Total Reflection X-ray Fluorescence (TXRF) Spectroscopy is a powerful multi-elemental technique with important applications in chemical analysis of biological and environmental samples. In the last years, there has been an increase in its use along this line. TXRF presents numerous advantages with respect to other techniques that are more frequently used, like ICP/MS, ICP/OES or AAS. It is a non-destructive technique, it requires a single standard internal calibration, it allows different types of samples (liquids, solutions, powder, suspensions, solid, thin films, aerosols) and it is possible to avoid digestion procedure. In addition, it is fast, simple, and it allows to detect and to quantify a great number of elements simultaneously from $\mathrm{Na}$ until $\mathrm{U}$ (including trace, ultra-trace and halogens) in ppb concentration until percent, it requires small sample amounts, it has high-sensitivity, low detection limits and it is inexpensive since it does not need the use of gases (e.g. argon).

Recently, a technical specification named ISO/TS 18507 "Surface chemical analysis-Use of Total Reflection $\mathrm{X}$-ray Fluorescence spectroscopy in biological and environmental analysis" [8] has been published. It summarizes all types of samples that can be analyzed by TXRF and the different kind of sample preparations; such as water, soil, plants, human and animal tissues and different fluids, among others that will be detailed in the next section.

Unlike the conventional XRF geometry and due to the low glancing beam angle, in TXRF the detector can be arranged closer to the sample leading to a higher fluorescence yield. The monochromatic X-ray beam illuminates the sample and it is totally reflected, leading to a doubling in the fluorescence intensity and significantly reducing background noise and matrix effects, which results in detection limits comparable or better to those that can be obtained by other techniques [8].

The S2 PICOFOX (Bruker) is the portable bench top TXRF spectrometer most employed for trace element analysis in the reviewed studies, but there are others. It is optimally suited, due to it allows for fast quantitative and semi-quantitative multi-element microanalysis of liquids, suspensions, solids and contaminations, reaching detection limits in the $\mu \mathrm{g} \mathrm{L}^{-1}$ and $\mathrm{mg} \mathrm{L}^{-1}$ range. The analysis time for sample is around of $300 \mathrm{~s}$.

The sample preparation is critical for the chemical analysis and it depends on the sample kind and its aggregate state [8]. There are many ways to treat the sample before conducting an analysis with TXRF. The liquids and suspensions samples can be evaluated directly (without pretreatment). Regarding the solid samples, they can be analyzed preparing a suspension or previously acid digestion [9]. In all cases, the sample must be dried with infrared light before to be measured by TXRF.

In TXRF is a not necessary realized curve of calibration, every time, before to measure. TXRF equipment is calibrated and you only must add a known amount of a standard internal to the sample. The use of an internal standard is required for quantification purposes, correcting any variation in sample deposition on the surface of reflector, which could produce random errors. Ga and Co are the most used internal standards. The only requirement is that the internal standard is not present in the sample to be analyzed.

\section{Environmental and biological applications}

In the last years, the numbers of investigations using TXRF spectrometry in environmental or biological studies has increased. The technical specification published in 2015 summarizes all types of samples that have been an- 
Table 1: List of works using TXRF in environmental and biological applications.

\begin{tabular}{|c|c|c|c|c|}
\hline Year & Authors & Type of sample & $\begin{array}{l}\text { Sample } \\
\text { preparation }\end{array}$ & Quantified elements \\
\hline \multirow{9}{*}{2014} & Álvarez-Vázquez, et al. [9] & Sediments & Slurry & As, $\mathrm{Cu}, \mathrm{Fe}, \mathrm{Mn}, \mathrm{Pb}, \mathrm{Rb}, \mathrm{Sr}, \mathrm{Ti}, \mathrm{V}, \mathrm{Zn}$ \\
\hline & \multirow[t]{2}{*}{ Cherkashina, et al. [10] } & $\begin{array}{l}\text { Geological samples (rock, } \\
\text { mineral, ore) }\end{array}$ & Suspensions & $\mathrm{Ba}, \mathrm{Br}, \mathrm{Ca}, \mathrm{Fe}, \mathrm{K}, \mathrm{Mn}, \mathrm{Ni}, \mathrm{Rb}, \mathrm{S}, \mathrm{Sr}, \mathrm{Zn}$ \\
\hline & & Natural water & None & \\
\hline & Yadav, et al. [11] & Human hair & Acid digestion & $\mathrm{Cr}, \mathrm{Cu}, \mathrm{Fe}, \mathrm{Ni}, \mathrm{Pb}, \mathrm{Zn}$ \\
\hline & Kubala-Kukus, et al. [12] & Human serum & Acid digestion & $\mathrm{Cu}$ \\
\hline & Lankosz, et al. [13] & Brain tumors & Acid digestion & $\mathrm{Ca}, \mathrm{Cu}, \mathrm{Fe}, \mathrm{K}, \mathrm{Rb}, \mathrm{Zn}$ \\
\hline & de Oliveira, et al. [14] & Honey & Suspensions & $\mathrm{Br}, \mathrm{Ca}, \mathrm{Cr}, \mathrm{Cu}, \mathrm{Fe}, \mathrm{K}, \mathrm{Mn}, \mathrm{Ni}, \mathrm{Se}, \mathrm{Sr}, \mathrm{Ti}, \mathrm{Zn}$ \\
\hline & Li, et al. [15] & Dwarf cherry & Acid digestion & $\mathrm{Ca}, \mathrm{Cu}, \mathrm{Fe}, \mathrm{K}, \mathrm{Mn}, \mathrm{P}, \mathrm{Rb}, \mathrm{S}, \mathrm{Sr}, \mathrm{Zn}$ \\
\hline & Marguí, et al. [16] & Edible clams & Acid digestion & Minor and trace elements \\
\hline \multirow{9}{*}{2015} & Bahadir, et al. [2] & Drinking water & None & $\mathrm{Cr}$ \\
\hline & Bilo, et al. [17] & Zebrafish embryos & None & $\mathrm{Pb}, \mathrm{Zn}$ \\
\hline & Feichtmeier, et al. [18] & Leaves and roots of the plants & Acid digestion & $\mathrm{Au}$ \\
\hline & Heroes, et al. [19] & Protein phosphatase & Slurry & $\mathrm{Fe}, \mathrm{Mn}, \mathrm{Zn}$ \\
\hline & de Olivera, et al. [20] & Honey & Suspensions & $\mathrm{Br}, \mathrm{Ca}, \mathrm{Cr}, \mathrm{Cu}, \mathrm{Fe}, \mathrm{K}, \mathrm{Mn}, \mathrm{Ni}, \mathrm{Se}, \mathrm{Sr}, \mathrm{Ti}, \mathrm{Zn}$ \\
\hline & Bilo, et al. [21] & $\begin{array}{l}\text { Rice } \\
\text { Soils }\end{array}$ & Acid digestion & $\begin{array}{l}\mathrm{Al}, \mathrm{As}, \mathrm{Ba}, \mathrm{Ca}, \mathrm{Cr}, \mathrm{Cu}, \mathrm{Fe}, \mathrm{K}, \mathrm{Mn}, \mathrm{Ni}, \mathrm{Pb} \\
\mathrm{Rb}, \mathrm{Sr}, \mathrm{Ti}, \mathrm{V}, \mathrm{Zn}\end{array}$ \\
\hline & Dalipi, et al. [22] & Wine & Dehydration & $\mathrm{Cl}, \mathrm{Cu}, \mathrm{Fe}, \mathrm{Mn}, \mathrm{Ni}, \mathrm{Pb}, \mathrm{Sr}, \mathrm{Zn}$ \\
\hline & $\begin{array}{l}\text { Espinosa-Quiñones, et al. } \\
\text { [23] }\end{array}$ & Groundwater & None & $\begin{array}{l}\text { As, Ba, Br, Ca, Cl, Co, Cr, Cu, Fe, K, Mn, Ni, } \\
\mathrm{P}, \mathrm{Pb}, \mathrm{S}, \mathrm{Ti}, \mathrm{V}, \mathrm{Zn}\end{array}$ \\
\hline & Detcheva, et al. [24] & Coalash & Slurry & $\begin{array}{l}\text { As, Ba, } \mathrm{Ca}, \mathrm{Cl}, \mathrm{Cr}, \mathrm{Cu}, \mathrm{Fe}, \mathrm{K}, \mathrm{Mn}, \mathrm{Ni}, \mathrm{Pb} \\
\mathrm{Rb}, \mathrm{Se}, \mathrm{Sr}, \mathrm{Ti}, \mathrm{V}, \mathrm{Zn}\end{array}$ \\
\hline \multirow{10}{*}{2016} & Cleto, et al. [6] & $\begin{array}{l}\text { Saliva and gingival crevice } \\
\text { fluid }\end{array}$ & None & $\begin{array}{l}\mathrm{Br}, \mathrm{Ca}, \mathrm{Cl}, \mathrm{Cu}, \mathrm{Fe}, \mathrm{K}, \mathrm{Mn}, \mathrm{P}, \mathrm{Pb}, \mathrm{Rb}, \mathrm{S}, \mathrm{Se} \\
\mathrm{Ti}, \mathrm{Zn}\end{array}$ \\
\hline & Kubala-Kukus, et al. [7] & $\begin{array}{l}\text { Human serum } \\
\text { Hair }\end{array}$ & $\begin{array}{l}\text { None } \\
\text { Acid digestion }\end{array}$ & $\mathrm{Pb}$ \\
\hline & Rodriguez Castro, et al. [25] & Superficial water & None & As, $\mathrm{Br}, \mathrm{Ca}, \mathrm{Fe}, \mathrm{K}, \mathrm{P}, \mathrm{Zn}$ \\
\hline & Majewska, et al. [26] & Human serum & None & $\mathrm{Br}, \mathrm{Ca}, \mathrm{Cl}, \mathrm{Cr}, \mathrm{Cu}, \mathrm{Fe}, \mathrm{K}, \mathrm{P}, \mathrm{Pb}, \mathrm{Rb}, \mathrm{S}, \mathrm{Se}, \mathrm{Zn}$ \\
\hline & Dalipi, et al. [27] & Wine & None & $\begin{array}{l}\mathrm{Ag}, \mathrm{Ba}, \mathrm{Bi}, \mathrm{Ca}, \mathrm{Cd}, \mathrm{Co}, \mathrm{Cr}, \mathrm{Cu}, \mathrm{Fe}, \mathrm{In}, \mathrm{K} \\
\mathrm{Mn}, \mathrm{Ni}, \mathrm{Pb}, \mathrm{Rb}, \mathrm{Sr}, \mathrm{Ti}, \mathrm{Zn}\end{array}$ \\
\hline & Gallardo, et al. [28] & Soil & Suspensions & $\mathrm{Br}$ \\
\hline & Fiedor, et al. [29] & $\begin{array}{l}\text { Bacteria and photosynthetic } \\
\text { structures }\end{array}$ & None & $\mathrm{Ca}, \mathrm{Co}, \mathrm{Cr}, \mathrm{Cu}, \mathrm{Fe}, \mathrm{K}, \mathrm{Mn}, \mathrm{Ni}, \mathrm{Rb}, \mathrm{Se}, \mathrm{Sr}, \mathrm{Zn}$ \\
\hline & Höhner, et al. [30] & Plant & Acid digestion & $\mathrm{Ca}, \mathrm{K}, \mathrm{Mn}, \mathrm{S}, \mathrm{Sr}$ \\
\hline & $\begin{array}{l}\text { Resende and Nascentes } \\
{[31]}\end{array}$ & Organic fertilizer & Slurry & $\begin{array}{l}\mathrm{Ba}, \mathrm{Br}, \mathrm{Ca}, \mathrm{Cl}, \mathrm{Cr}, \mathrm{Cu}, \mathrm{Fe}, \mathrm{K}, \mathrm{Mn}, \mathrm{Ni}, \mathrm{P}, \mathrm{Pb} \\
\mathrm{Rb}, \mathrm{S}, \mathrm{Sr}, \mathrm{Ti}, \mathrm{V}, \mathrm{Zn}\end{array}$ \\
\hline & Natali, et al. [32] & Mosses & Slurry & $\begin{array}{l}\mathrm{Al}, \mathrm{As}, \mathrm{Br}, \mathrm{Ca}, \mathrm{Ce}, \mathrm{Cl}, \mathrm{Cr}, \mathrm{Cu}, \mathrm{Fe}, \mathrm{K}, \mathrm{Mn}, \mathrm{Ni} \\
\text { V, P, Pb, Rb, S, Sr, Ti, Zn }\end{array}$ \\
\hline \multirow{8}{*}{2017} & Dalipi, et al. [3] & Vegetal sample & Suspensions & $\begin{array}{l}\text { As, Br, } \mathrm{Ca}, \mathrm{Cu}, \mathrm{Fe}, \mathrm{K}, \mathrm{Mn}, \mathrm{Rb}, \mathrm{Sn}, \mathrm{Sr}, \mathrm{Pb} \\
\mathrm{Zn}\end{array}$ \\
\hline & Salomone, et al. [4] & Seaweed & Acid digestion & $\mathrm{As}, \mathrm{Br}, \mathrm{Cu}, \mathrm{Cr}, \mathrm{Fe}, \mathrm{Mn}, \mathrm{Ni}, \mathrm{Pb}, \mathrm{Rb}, \mathrm{Sr}, \mathrm{V}, \mathrm{Zn}$ \\
\hline & Bandeira Lages, et al. [33] & Saliva & Acid digestion & $\mathrm{Cr}, \mathrm{Cu}, \mathrm{Fe}, \mathrm{Ni}$ \\
\hline & Almeida, et al. [34] & Mice brain & Acid digestion & $\mathrm{Ca}, \mathrm{Cl}, \mathrm{Cu}, \mathrm{Fe}, \mathrm{K}, \mathrm{Ni}, \mathrm{P}, \mathrm{S}, \mathrm{Zn}$ \\
\hline & Jablan, et al. [35] & Urine & None & $\mathrm{Ca}, \mathrm{Cu}, \mathrm{Co}, \mathrm{Fe}, \mathrm{K}, \mathrm{Mn}, \mathrm{Na}, \mathrm{P}, \mathrm{Se}, \mathrm{Zn}$ \\
\hline & Allegretta, et al. [36] & $\begin{array}{l}\text { Celomic fluids from } \\
\text { earthworms }\end{array}$ & None & As \\
\hline & Marguí, et al. [37] & Human placenta & $\begin{array}{l}\text { Slurry } \\
\text { Acid digestion }\end{array}$ & $\mathrm{As}, \mathrm{Br}, \mathrm{Ca}, \mathrm{Cd}, \mathrm{Cu}, \mathrm{Fe}, \mathrm{K}, \mathrm{Pb}, \mathrm{Rb}, \mathrm{Se}, \mathrm{Sr}, \mathrm{Zn}$ \\
\hline & Bilo, et al. [38] & Tree leaves & $\begin{array}{l}\text { None } \\
\text { Acid digestion }\end{array}$ & $\mathrm{Br}, \mathrm{Ca}, \mathrm{Cl}, \mathrm{Cr}, \mathrm{Cu}, \mathrm{Fe}, \mathrm{K}, \mathrm{Mn}, \mathrm{Pb}, \mathrm{Rb}, \mathrm{Sr}, \mathrm{Ti}, \mathrm{Zn}$ \\
\hline
\end{tabular}

alyzed by TXRF with environmental purposes until 2013 [8]. Before that, Szoboszlai, et al. [10] published a review focused on the application of TXRF in the field of biological research. They concluded that, the TXRF method is still not popular enough and others elemental labora- tory analyses mostly are applied (i.e. AAS, ICP/OEs or ICO/MS). The present work reviews the researches of the last years (Table 1). During 2014, eight papers used this valuable technique for determination of multi-elemental composition in different types of samples. Such as geo- 
logical samples [11,12], human samples [13-15] and food [16-18]. In 2015, nine papers were published on the use of TXRF in environmental and biological studies. Among biological samples, animal and plant tissues $[19,20]$, proteins [21] and food (honey, rice, wine) [22-24] are found. Regarding environmental research, groundwater [25], drinking water [2], soils [23] and ash [26] were analyzed by TXRF. During 2016, ten papers were published about TXRF in environmental and biological applications (Table 1). Among them superficial water samples [27], human biological materials and fluids [6,7,28], wine [29], soil [30], organic samples (bacteria, plant, mosses, fertilizer) [31-34] were analyzed. So far this year, eight papers have been published [3,4,35-40]. Among them, a new type of sample appears, such as, seaweed [4]. There were no papers on multi-elemental analysis in marine algae by TXRF. Salomone, et al. [4] showed that the technique is adequate for studies on chemical composition of marine macro algae, previously digested.

The main advantages of the methodology are the consumption of low volumes of reagents and the low operating costs since the portable TXRF system used does not require cooling media and gas for operation. In addition, the method is fast, simultaneous multi-elemental analysis takes place at room temperature, preventing analyte losses due to volatilization and a small amount of sample is enough for the analysis, regard less of sample pretreatment. Dalipi, et al. [29] emphasized on the easy quantification through internal standardization and low operating costs, since the bench top system used does not require cooling media and gas consumption for functioning. Rodriguez Castro, et al. [27] proved that TXRF technique is suited for evaluating water of different sources with adequate detection limits and excellent sensitivity for trace elements. In addition, no sample preparation is required for these types of samples, which is a benefit because also it prevents possible contamination by other processes and it is less time consuming. Numerous works prove that TXRF is quite suitable for routine analysis of human biological material (e.g. serum, urine, saliva and hair), because it lets to determine simultaneously many elements in one measurement in a very small amount of samples and in some cases directly $[6,13,28]$. Gallardo, et al. [30] used TXRF method to determine $\mathrm{Br}$ content in two real soil extracts, showing that it is possible to quantify halogens Resende and Nascentes [33] expressed the ability of TXRF to quantify many analytes, including $\mathrm{P}, \mathrm{S}, \mathrm{Cl}$ and $\mathrm{Br}$, for which the determination by others spectrometric techniques is more difficult. Fiedor, et al. [31] evaluated the application of TXRF spectrometry to provide an elemental profile of bacteria and their photosynthetic structures. The method proved its value in studies where the samples are highly limited in amount and concentration. Höhner, et al. [32] highlighted that
TXRF is especially suited to probe individual leaves in single plants or even specific leaf areas due to that very small amount of samples that are required $(<0.5 \mathrm{mg}$ dry weight). In addition, it is cost-efficient suitable, precise, robust and highly reproducible.

The papers prove that the TXRF applications are infinite and show the advantages of the use of TXRF in the multi-element analysis, highlighting the low cost, the small amount of sample required and the possibility of avoiding the digestion of the samples simplifying the procedure and reducing the total analysis time. Natali, et al. [34] determined a great number of elements in mosses by a TXRF coupled with a slurry sampling method (slurry-TXRF). It is an advantage in comparison with other techniques because the method avoids a digestion step and reduces the risk of sample contamination. The same sample preparation was used for soils, organic fertilizer, ash, honey, among others [16,26,30,33].

\section{TXRF limitations}

TXRF technique has limitations. Some of them are related with the sample or its preparation. For example, it is not possible determinate cadmium or mercury when the sample was previously digested, because, these elements are lost in during the process. Others restrictions are connected to operating conditions from spectrometer, as the type of X-ray tube (tungsten, molybdenum). In addition, there are some limitations regarding to detections limits of some elements. In that sense, the use of synchrotron light can improve the detection limits significantly, making possible detect amounts in the fentograms order. Kunimura, et al. [41] described a method for improving the detection limit for zinc by a portable TXRF spectrometer. Hampai, et al. [42] demonstrated that a conventional source combined with a polycapillary semi-lens can provide a quasi-parallel beam intense enough for desktop TXRF analysis of low concentration samples.

\section{Conclusions}

The samples heterogeneity and different types of sample preparation or pretreatment confirm the versatility of this technique, which is still new for biological and environmental studies. The small amount of sample required combined with a portable equipment, simple and that it does not require much maintenance, it does not use gases and it has a low cost with respect to other equipment (like ICP, which also has more sophisticated installation conditions), makes the analysis with this technique easier, cheaper and accessible to any laboratory of biological, analytic or environmental analysis. The results are easy to obtain, visualize and analyze, no technicians or specially trained staff are required. The data are accurate and quantified with high sensitivity and low detection limit. 
Studies of chemical composition are interesting for many reasons. From the environmental standpoint, knowing the content of heavy metals and metalloids in food and other biological samples is especially relevant for human health and ecosystem conservation. The human activities are responsible of environmental destruction, lost species and human diseases expansion. Knowing elemental composition in a fast and simple way is essential.

\section{References}

1. Borgese L, Bilo F, Dalipi R, Bontempi E, Depero LE (2015) Total reflection X-ray fluorescence as a tool for food screening. Spectrochim Acta B 113: 1-15.

2. Bahadir Z, Bulut VN, Hidalgo M, Soylak M, Marguí E (2015) Determination of trace amounts of hevalent chromium in drinking waters by dispersive microsolid phase extraction using modified multiwalled carbon nanotubes combined with total reflection X-ray fluorescence spectrometry. Spectrochim Acta B 107: 170-177.

3. Dalipi R, Marguí E, Borgese L, Depero L (2017) Multi-element analysis of vegetal foodstuff by means of low power total reflection X-ray fluorescence (TXRF) spectrometry. Food Chem 218: 348-355.

4. Salomone VN, Riera M, Cerchietti L, Custo G, Muniain C (2017) Seasonal determination of trace and ultra-trace content in Macrocystis pyrifera from San Jorge Gulf (Patagonia) by Total Reflection X-ray Fluorescence. Spectrochim Acta B 131: 74-78.

5. Morgada ME, Levy IK, Salomone VN, Farías SS, López $\mathrm{G}$, et al. (2009) Arsenic (V) removal with nanoparticulate zerovalent iron:Effect of UV light and humic acids. Catal Today 143: 261-268.

6. Cleto DAM, Casanova Andrello A, Netto IJV, Appoloni CR (2016) Analysis of saliva and gingival crevice fluid by total reflection X-ray fluorescence (TXRF). X-ray Spectrom 45: 220-224.

7. Kubala-Kukus A, Banas D, Majewska U, Stabrawa I, WudarczykMacko J, et al. (2016) Determination of lead at physiological level in human biological materials using the total reflection X-ray fluorescence analysis. X-ray Spectrom 45: 318-324.

8. ISO 18507 (2015) Surface chemical analysis-Use of Total Reflection X-ray Fluorescence spectroscopy in biological and environmental analysis.

9. De La Calle I, Cabaleiro N, Romero V, Lavilla I, Bendicho C (2013) Sample pretreatment strategies for total reflection X-ray fluorescence analysis: A tutorial review. Spectrochim Acta B 90: 23-54.

10. Szoboszlai N, Polgári Z, Mihucz VG, Záray G (2009) Recent trends in total reflection $X$-ray fluorescence spectrometry for biological applications. Anal Chim Acta 633: 1-18.

11. Álvarez-Vázquez MA, Bendicho C, Prego R (2014) Ultrasonic slurry sampling combined with total reflection $\mathrm{X}$-ray spectrometry for multi-elemental analysis of coastal sediments in ria system. Microchem J 112: 172-180.

12. Cherkashina TY, Penteeva SV, Pashkova GV (2014) Applicability of direct total reflection X-ray fluorescence spectrometry for multielement analysis of geological and environmental objects. Spectrochim Acta B 99: 59-66.

13. Yadav VB, Pillay RH, Jha SK (2014) Application of total re- flection X-ray fluorescence spectrometry for multi-elements characterization in human hair. $\mathrm{J}$ Radioanal Nucl Chem 300: $57-60$.

14. Kubala-Kukus A, Banas D, Braziewicz J, Majewska U, Pajek M, et al. (2014) Analysis of copper concentration in human serum by application of total reflection X-ray fluorescence method. Biol Trace Elem Res 158: 22-28.

15. Lankosz MW, Grzelak M, Ostachowicz B, Wandzilak A, Szczerbowska-Boruchowska M, et al. (2014) Application of the total reflection X-ray fluorescence method to the elemental analysis of brain tumors of different types and grades of malignancy. Spectrochim Acta B 101: 98-105.

16. De Oliveira Resende Ribeiro R, Texeira Mársico E, Oliveira de Jesus EF, da Silva Carneiro $C$, Conte Júnior $C A$, et al. (2014) Determination of trace elements in honey from different regions in Rio de Janeiro State (Brazil) by total reflection X-ray fluorescence. J Food Sci 79: 738-742.

17. Li WD, Li O, Mo C, Jiang YS, He Y, et al. (2014) Mineral element composition of 27 chinese dwarf cherry (Cerasus humilis (Bge) Sok) genotypes collected in Chine. J Hortic Sci Biotech 89: 674-678.

18. Marguí E, de Fátima Marques A, de Lurses Prisal M, Hidalgo M, Queralt I, et al. (2014) Total reflection X-ray Spectrometry (TXRF) for trace elements assessment in edible clams. Appl Spectrosc 68: 1241-1246.

19. Bilo F, Moscoso S, Borgese L, Delbarba MV, Zacco A, et al. (2015) Total reflection X-ray fluorescence spectroscopy to study $\mathrm{Pb}$ and $\mathrm{Zn}$ accumulation in zebrafish embryos. X-ray Spectrom 44: 124-128.

20. Feichtmeier NS, Walther P, Leopold K (2015) Uptake, effects and regeneration of barley plants exposed to gold nanoparticles. Environ Sci Pollut Res 22: 8549-8558.

21. Heroes E, Rip J, Beullens M, Meervelt LV, De Gendt S, et al. (2015) Metals in the active site of native protein phosphatase-1. J Inorg Biochem 149: 1-5.

22. De Olivera Resende Ribeiro R, Teixeira Mársico E, da Silva Carneiro C, Siqueira Simoes J, da Silva Ferreira M, et al. (2015) Seasonal variation in trace and minor elements in Brazilian honey by total reflection X-ray fluorescence. Environ Monit Assess 187: 96.

23. Bilo F, Lodolo M, Borgese L, Bosio A, Benassi L, et al. (2015) Evaluation of heavy metals contamination from environment to food matrix by TXRF: The case of rice and rice husk. J Chem 1-12.

24. Dalipi R, Borgese L, Zacco A, Tsuji K, Sangiorgi E, et al. (2015) Determination of trace elements in Italian wines by means of total reflection X-ray fluorescence spectroscopy. Int J Environ An Chem 95: 1208-1218.

25. Espinosa-Quiñones F, Módenes AN, de Pauli AR, Palacio SM (2015) Analysis of trace elements in groundwater using ICP-OES and TXRF techniques and its compliance with Brazilian protection standards. Water Air Soil Pollut 226: 32-44.

26. Detcheva AK, Mitsiev SE, Vassileva PS, Jordanov JH, Karadjov MG, et al. (2015) Total reflection X-ray fluorescence analysis of fly ash from Bulgarian coal-fired power plants. Chemical Papers 69: 650-654.

27. Rodriguez Castro MC, Vilches C, Torremorell A, Vázquez C, Giorgi A (2016) Total reflection $X$ ray fluorescence in 
environmental and geochemical studies: unveiling solute provenance in streams during a rain episode. X-ray Spectrom 45: 225-232.

28. Majewska U, Luzwa P, Luzwa K, Banas D, Kubala-Kukus A, et al. (2016) Determination of elements levels in human serum: total reflection X-ray fluorescence applications. Spectrochim Acta B 122: 56-61.

29. Dalipi R, Marguí E, Borgese L, Bilo F, Depero LE (2016) Analytical performance of benchtop total reflection X-ray fluorescence instrumentation for multielemental analysis of wine samples. Spectrochim Acta B 120: 37-43.

30. Gallardo H, Queralt I, Tapias J, Candela L, Marguí E (2016) Bromine and bromide content in soils: Analytical approach from total reflection X-ray fluorescence spectrometry. Chemosphere 156: 294-301.

31. Fiedor J, Ostachowicz B, Baster M, Lankosz M, Burda K (2016) Quantification of purple non-sulphur phototrophic bacteria and their photosynthetic structures by means of total reflection X-ray fluorescence spectrometry (TXRF). J Anal At Spectrom 31: 2078-2088.

32. Hóhner R, Tabatabaei S, Kunz HH, Fittschen U (2016) A rapid total reflection $\mathrm{X}$-ray fluorescence protocol for micro analyses of ion profiles in Arabidopsis thaliana. Spectrochim Acta B 125: 159-167.

33. Resende LV, Nascentes CC (2016) A simple method for the multi-elemental analysis of organic fertilizer by slurry sampling and total reflection X-ray fluorescence. Talanta 147: 485-492.

34. Natali M, Zanella A, Rankovic A, Banas D, Cantaluppi C, et al. (2016) Assessment of trace metal air pollution in Paris using slurry-TXRF analysis on cemetery mosses. Environ Sci Pollut Res 23: 23496-23510.
35. Bandeira Lages R, Coser Bridi E, Pérez CA, Tarkany Basting $R$ (2017) Salivary levels of nickel, chromium, iron and copper in patients treated with metal or esthetic fixed orthodontic appliances: A retrospective cohort study. J Trace Elem Med Bio 40: 67-71.

36. Almeida DS, Santos RS, Anjos MJ, Ferreira ST, Souza AS, et al. (2017) Multielement concentration analysis of swiss mice brains on experimental model of Alzheime's disease induced by $\beta$-amyloid oligomers. X-ray Spectrom.

37. Jablan J, Inic S, Stosnach H, Hadziabdic MO, Vujic L, et al. (2017) Level of minerals and trace elements in the urine of the participants of mountain ultra-marathon race. J Trace Elem Med Bio 41: 54-58.

38. Allegretta I, Porfido C, Panzarino O, Fontanella MC, Beone GM, et al. (2017) Determination of As concentration in earthworm coelomic fluid extracts by total reflection X-ray fluorescence spectrometry. Spectrochim Acta B 130: 21-25.

39. Marguí E, Ricketts $P$, Fletcher $H$, Karydas AG, Migliori A, et al. (2017) Total reflection X-ray fluorescence as a fast multielemental technique for human placenta sample analysis. Spectrochim Acta B 130: 53-59.

40. Bilo F, Borgese L, Dalipi R, Zacco A, Federici S, et al. (2017) Elemental analysis of tree leaves by total reflection X-ray fluorescence: New approaches for air quality monitoring. Chemosphere 178: 504-512.

41. Kunimura S, Sugawaga Y, Kudo S (2017) Reduction of spectral interference between $X$-ray peaks originating from an X-ray tuve and X-ray fluorescence peaks in total reflection X-ray fluorescence analysis. ISIJ Inter 57: 953-955.

42. Hampai D, Dabagov SB, Polese C, Liedl A, Cappuccio G (2014) Laboratory total reflection X-ray fluorescence analysis for low concentration samples. Spectrochim Acta B 101: 114117. 